\title{
Pharmacologic Neuroimaging of the Ontogeny of Dopamine Receptor Function
}

\author{
Y. Iris Chen ${ }^{\mathrm{a}}$ Ji-Kyung Choi ${ }^{\mathrm{a}}$ Haibo $\mathrm{Xu}^{\mathrm{c}}$ Jiaqian Ren ${ }^{\mathrm{a}}$ Susan L. Andersen ${ }^{\mathrm{b}}$ \\ Bruce G. Jenkins ${ }^{\text {a }}$ \\ ${ }^{a}$ Athinoula A. Martinos Center for Biomedical Imaging, Department of Radiology, Massachusetts General Hospital, \\ Harvard Medical School, Charlestown, Mass., and ${ }^{b}$ Developmental Psychopharmacology Laboratory, \\ McLean Hospital, Belmont, Mass., USA; ${ }^{C}$ Union Hospital, Wuhan, China
}

\section{Key Words}

Ontogeny $\cdot$ Dopamine $\cdot \mathrm{D} 1$ receptor $\cdot \mathrm{D} 2$ receptor .

Functional MRI $\cdot$ Pharmacological MRI

\begin{abstract}
Characterization of the ontogeny of the cerebral dopaminergic system is crucial for gaining a greater understanding of normal brain development and its alterations in response to drugs of abuse or conditions such as attention-deficit hyperactivity disorder. Pharmacological MRI (phMRI) was used to determine the response to dopamine transporter (DAT) blockers cocaine and methylphenidate (MPH), the dopamine releaser $\mathrm{D}$-amphetamine (AMPH), the selective D1 agonist dihydrexidine, and the D2/D3 agonist quinpirole in young ( $<30$ days old) and adult ( $>60$ days old) rats. In adult rats, cocaine $(0.5 \mathrm{mg} / \mathrm{kg}$ i.v.) or MPH ( $2 \mathrm{mg} / \mathrm{kg})$ induced primarily positive cerebral blood volume ( $\mathrm{CCBV}$ ) changes in the dopaminergic circuitry, but negative rCBV changes in the young animals. Microdialysis measurements in the striatum showed that young rats have a smaller increase in extracellular dopamine in response to cocaine than adults. The young rats showed little rCBV response to the selective D1 agonist dihydrexidine in contrast to robust $\mathrm{rCBV}$ increase observed in the adults, whereas there was a similar nega-
\end{abstract}

tive $\mathrm{rCBV}$ response in the young and adult rats to the D2 agonist quinpirole. We also performed a meta-analysis of literature data on the development of D1 and D2 receptors and the DAT. These data suggest a predominance of D2-like over D1-like function between 20 and 30 days of age. These combined results suggested that the dopamine D1 receptor is functionally inhibited at young age.

Copyright $\odot 2010$ S. Karger AG, Basel

\section{Introduction}

Drug abuse may be considered a developmental disorder. Stimulant abuse increases from 2.9 to $16.4 \%$ between 12 and 16 years of age [Johnstone et al., 2007]. Aside from the important social aspects, the vulnerability of adolescents to stimulant abuse may also be related to maturational changes associated with the dopaminergic system. Between childhood, adolescence, and adulthood, the brain undergoes marked structural changes including decreases in cortical volume [Gogtay et al., 2004; O'Donnell et al., 2005; Shaw et al., 2008], development of plasticity via massive synaptic pruning [Huttenlocher, 1984; Zecevic et al., 1989], alteration of dopamine (DA) and glutamate receptor density [Gelbard et al., 1989;

\section{KARGER}

(C) 2010 S. Karger AG, Basel

Fax +41613061234 E-Mail karger@karger.ch www.karger.com www.karger.com/dne
$\mathrm{Y}$. Iris Chen, $\mathrm{PhD}$, and Bruce $\mathrm{G}$. Jenkins, $\mathrm{PhD}$

Martinos Center for Biomedical Imaging

Rm 2301, Bldg. 149, 13th Street, Charlestown, MA 02129 (USA)

Tel. +1 6177267873 , Fax +1 6177267422

E-Mail iris@nmr.mgh.harvard.edu.or bgj@nmr.mgh.harvard.edu 
Court et al., 1993], and changes in neurochemical (e.g. DA) transmission [Kalsbeek et al., 1988; Teicher et al., 1993; Anderson et al., 1997]. Despite these ontogenic observations, the underlying mechanisms and their functional impacts are still unclear. Further, although there is a relatively large body of data collected going back over 30 years, the precise timing of maturational changes in the DA system are not fully determined, as we demonstrate below using meta-analyses of the existing data.

Stimulants such as cocaine or methylphenidate $(\mathrm{MPH})$ work by increasing DA levels, through blockade of the dopamine transporter (DAT) or direct release in the case of amphetamine. A number of studies, including this one, suggest that stimulant-induced release is lower in juvenile animals than adults [Andersen and Navalta, 2004; Cao et al., 2007]. Functionally, DA receptors have transient inhibitory effects on DA transmission before adolescence that disappear by adulthood [Kalsbeek et al., 1988; Teicher et al., 1993; Anderson et al., 1997], although the full functional significance of these rearrangements is not understood. Most of the knowledge we have so far about the development of the adolescent brain is via ex vivo study. Although postmortem brains provide detailed information, such as synaptic and receptor density and neuronal status at a fixed point in time, information about neuronal activity at a fully functional stage is hard to assess. Changes in hemodynamics - cerebral blood flow or regional cerebral blood volume (rCBV) - may offer unique insight into the functional consequences of such receptor changes. DA function can be assessed by hemodynamic changes via pharmacological MRI (phMRI) using many dopaminergic ligands. D-Amphetamine (AMPH) induces hemodynamic changes correlated to synaptic DA concentrations [Chen 1997; Chen et al., 2005]. phMRI can also assess the functional status of D1- and D2-like receptor families (D1R and D2R). D1/D5 agonists produce positive hemodynamic changes linking to the excitatory D1 agonism, whereas D2/D3 receptor agonists produced negative hemodynamic changes linking to the inhibitory D2/D3 agonism [Chen et al., 2005; Choi et al., 2006]. Although hemodynamic measurements are an indirect index for DA function (when challenged with DA ligands), they measure the system as a whole, including function from DA receptor subtypes (D1R or D2R) and their impacts on other neurotransmitters as well as the postsynaptic signaling pathways.

In this manuscript, we used phMRI with several classes of dopaminergic ligands in an attempt to characterize dopaminergic function in young and adult rats. Specifically, we used a variety of DAT blockers to increase the synaptic DA concentration to test the gross dopaminergic function. The functional state of D1R and D2R was tested by challenging rats with $\mathrm{D} 1$ agonist dihydrexidine (DHDD) and D2/D3 agonist quinpirole, respectively. Hypercapnia experiments in young and adult rats were also carried out to ensure that the hemodynamic response was not hindered by a non-fully developed vascular response in the young rats. In addition to phMRI, DA efflux in response to cocaine challenge was measured using microdialysis in a subgroup of animals. Taken together, pharmacologically produced changes in $\mathrm{rCBV}$ provide a noninvasive method for studying receptor function and can be applied to other species.

\section{Materials and Methods}

\section{Animals}

Male Sprague-Dawley rats (Charles River Laboratories, Wilmington, Mass., USA) at juvenile age (postnatal days 22-29, P2229 ) or adults ( $>$ P60, range 9-15 weeks, 300-450 g) were used in this study. Rats were housed and provided with food and water ad libitum for at least 7 days before the study. Rats in the young group were initially housed with their mothers. Those studied at P22 were still housed with the mothers. Those studied at P28-29 had already been weaned. A 12-hour light/dark cycle was used (from 7 a.m. to 7 p.m.). All procedures were conducted in accordance with the National Institute of Health Guide for the Care and Use of Laboratory Animals (NIH Publications No. 80-23) revised 1996. Animals were anesthetized with $1 \%$ halothane in mixture gas of $\mathrm{O}_{2}$ and air (1:1). All animals were free breathing, except the group receiving cocaine who were mechanically ventilated to prevent hyperventilation. A water-heating pad was used to regulate the core temperature. An intravenous catheter was placed into the tail vein percutaneously for drug administration. In a subgroup of animals, the femoral artery was catheterized for blood pressure and blood gas sampling. Blood pressure and blood gas were not available for the juveniles due to the tiny size of arterial catheterization. Blood oxygenation (pulse oximeter; Nonin Medical, Minn., USA) was monitored via an optical sensor clipping on the hindpaw. Rats were secured to a standard stereotaxic frame (for microdialysis study) or an imaging cradle through a pair of ear bars and a ventilation mask with tooth bar. A homemade singleloop surface coil was then placed on top of the head to receive the MR signal.

Drugs

All dopaminergic ligands (AMPH, sulfate, cocaine, MPH, dihydrexidine, and quinpirole) were obtained from Sigma (St. Louis, Mo., USA). The dextran-coated superparamagnetic intravascular contrast agent of monocrystalline iron oxide nanoparticle (MION) was synthesized in our laboratory according to Shen et al. [1993]. Our choice of dose for the drugs was based upon the following logic. The DAT blockers cocaine and MPH will produce between a 250 and $350 \%$ increase in basal DA efflux at the doses we chose $(0.5 \mathrm{mg} / \mathrm{kg}$ and $2 \mathrm{mg} / \mathrm{kg}$ i.v. for cocaine and $\mathrm{MPH}$, re- 


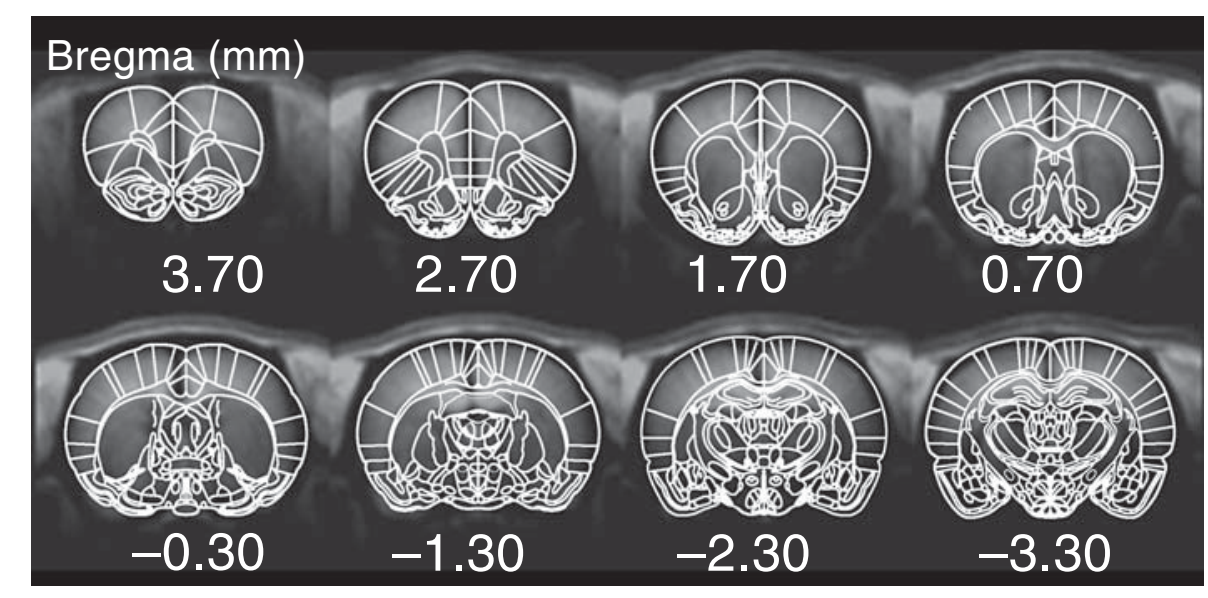

Fig. 1. After brain normalization and coregistration, ROIs were segmented according to the rat brain atlas [Paxinos and Watson, 1997].

spectively) [Kuczenski et al., 1991; Aoyama et al., 1997; Kraft et al., 2001; Tanda et al., 2005; Cao et al., 2007]. DA releasers, such as amphetamine, can be expected to produce much larger increases in DA efflux for comparable doses. At the dose of amphetamine we chose $(1 \mathrm{mg} / \mathrm{kg})$, there is approximately a $1,300 \%$ increase in basal efflux [Kuczenski et al., 1991; Chen et al., 1997, 2005; Choi et al., 2006; Ren et al., 2009]. This much higher level of DA efflux allows us to test the hypothesis that there will be stimulation of D1-like receptors leading to positive CBV changes in this dose range. Attaining such a high level of DA release with the DAT blockers would entail administering doses close to the $\mathrm{LD}_{50}$ ranges. The doses for the D1 agonist DHDD ( $3 \mathrm{mg} / \mathrm{kg}$ ) and D2 agonist quinpirole $(2 \mathrm{mg} / \mathrm{kg})$ were chosen to be ranges that we had previously shown to produce robust CBV changes [Chen et al., 2005; Choi et al., 2006].

\section{Pharmacological MRI}

All phMRI experiments were performed on a 9.4-T Bruker scanner (Billerica, Mass., USA). A long-lived intravascular superparamagnetic contrast agent, MION [Shen et al., 1993], was used to sensitize the MR signal to rCBV changes [Villringer et al., 1988] with the benefits of increased sensitivity and stability in phMRI experiments [Chen et al., 2001; Mandeville et al., 2004]. Due to the fast hemodynamic response to cocaine, echo planar imaging (16 shot gradient echo, TR $625 \mathrm{~ms}$, TE $6 \mathrm{~ms}$, matrix size $80 \times 80$, temporal resolution $10 \mathrm{~s} /$ volume) was used to acquire functional data. For all the other drugs which have a long pharmaco-hemodynamic half-life, functional data were acquired using a conventional gradient echo sequence (TR $300 \mathrm{~ms}$, TE $6 \mathrm{~ms}$, matrix size $128 \times 128$, temporal resolution $38 \mathrm{~s}$ /volume) in order to trade temporal resolution for a better spatial resolution. In order to match the size differences at different ages, we used a field of view of $3 \mathrm{~cm}$ and slice thickness of $1 \mathrm{~mm}$ for adult rats and a field of view of $2.65 \mathrm{~cm}$ and slice thickness of $0.65 \mathrm{~mm}$ for juvenile rats. An exact match was not critical since 'coregistration' automatically corrected the size differences. MION (10-15 mg/kg, i.v.) was injected after collection of baseline images. At least 15 post-MION baseline images were collected before administration of pharmacological ligands or hypercapnia challenge $\left(7.5 \% \mathrm{CO}_{2}\right.$ for $\left.10 \mathrm{~min}\right)$. Then repeated acquisitions continued for 30-90 min after drug stimulus (depending on the pharmacokinetics of the drug).

\section{Anatomic Registration and Segmentation}

To facilitate comparisons between animals, all functional images were registered onto a standard template according to the rat brain atlas [Paxinos and Watson, 1997] using an automatic routine developed by Dr. J.B. Mandeville at Massachusetts General Hospital. Although minimal motion was expected during a functional scan due to the fact that animals were anesthetized and secured in a head holder, minor motion was corrected using the AFNI subroutine '3dvolreg' [Cox and Hyde, 1997]. Registration between the functional image set and the standard template was performed by adjusting 9 registration variables ( 3 spatial shifts, 3 rotation angles, and 3 skew - non-rigid - angles on the 3 major planes). Anatomical landmarks were used to resize the brain along the 3 major axes to match the size from the standard template. This step was particularly useful for aligning brains at different ages. Regions of interest (ROIs) were segmented according to the rat brain atlas [Paxinos and Watson, 1997] (fig. 1), and applied to each functional run. We characterized the average inflations required to register the young and adult brains to the Paxinos atlas. These numbers include both differences reflective of age as well as between Wistar and Sprague-Dawley rats (those used in this study) and finally differences due to distortions that might be caused by gradient echo imaging. The average inflations required in the young animals (P20-30) were $\mathrm{x}, \mathrm{y}, \mathrm{z}=1.117 \pm 0.008,1.111$ $\pm 0.019,1.095 \pm 0.0487$, respectively, and in the adults these were $\mathrm{x}, \mathrm{y}, \mathrm{z}=1.071 \pm 0.011,1.050 \pm 0.008,1.010 \pm 0.008$, respectively. These numbers are reasonably close to 1 (the expected value) and are not likely to affect our analysis given that we report ROIs for relatively large brain areas (such as the caudate/putamen, $\mathrm{CPu}$ ). The methods we used are quite similar to those reported in previous human studies, and are also similar to those reported in other animal phMRI studies [Schwarz et al., 2006].

phMRI rCBV Time Course Characterization

Maps of rCBV responses were calculated on a pixel-by-pixel basis as previously described [Chen et al., 2001; Mandeville et al., 2001; Mandeville et al., 2004; Chen et al., 2005]. The rCBV time course was characterized using a 'general linear model' (GLM) with $\gamma$-function $[f \times \mathrm{t} \times \exp (-\mathrm{t} / \tau)]$, where $\tau$ represents the peak time of the $\gamma$-curve and $f$ is the amplitude coefficient. Depending on the characteristics of the time courses, some of the drugs re- 
quired more than one $\gamma$-function to fully describe the time curve. For example, the cocaine-induced biphasic rCBV change was best described by two $\gamma$-functions, with one for the negative peak and another one for the delayed positive peak.

Activation Maps. The statistical p value of the GLM fitting was generated on a pixel-by-pixel basis. In addition, maps of peak or average $\mathrm{rCBV}$ values were generated. The rCBV amplitude map was masked (threshold) by GLM p value $\left(\mathrm{p}<10^{-10}\right)$. Note that the GLM fitting is solely for illustration purposes (i.e. activation maps) and data analysis is based on raw rCBV timecourse, which is unbiased by the choice of fitting function. Also, since the statistical power of our phMRI data with MION is typically quite strong, minor changes in the fitting functions (such as $\gamma$-function or others) make little differences in the maps obtained. The CBV values for each drug were averaged over time blocks corresponding to the length of the hemodynamic response, which we have previously shown reflects the DA efflux time course [Chen et al., 1997; Chen et al., 2005; Choi et al., 2006]. Values were 0-10 min for cocaine, 0-20 min for MPH, 0-50 min for AMPH, 0-50 min for DHDD, and 0-40 min for quinpirole. Comparisons between groups (young and adult) were performed using a one-way ANOVA for each brain region.

ROI Analysis. Raw rCBV time courses from predefined ROIs were obtained for ROI analysis. Both activation map and ROI analyses were performed at individual and group levels.

\section{Microdialysis}

Microdialysis was conducted in separate groups of rats (adults: $\mathrm{n}=5$, P22 rats: $\mathrm{n}=4$ ) to access the DA concentration upon cocaine challenge $(0.5 \mathrm{mg} / \mathrm{kg}$ i.v.). In order to compare the results of microdialysis to phMRI, rats were anesthetized (halothane, $1 \%$ in 1:1 air/ $\mathrm{O}_{2}$ mixture) but there was no MION injection involved in the microdialysis protocol. Preparation for microdialysis in the $\mathrm{CPu}$ were carried out as previously described [Chen et al., 2005]. The dialysate probe was inserted into the $\mathrm{CPu}$ (coordinates for adults were AP 0.48, ML 3.2, and DV -7.3 [Paxinos and Watson, 1997] and for P22 rats these were $0.35,2.7$, and -5.8 , respectively, adjusted according to scales of MR anatomical images in the 2 age groups). Continuous infusion of artificial CSF (125 $\mathrm{mM} \mathrm{NaCl}, 2.5 \mathrm{mM} \mathrm{KCl}, 1.2 \mathrm{CaCl}_{2}, 1.0 \mathrm{mM} \mathrm{MgCl}_{2}$, and $0.2 \mathrm{mM} \mathrm{L}-$ ascorbic acid at $\mathrm{pH} 7.4)$ was delivered at $2 \mu \mathrm{l} / \mathrm{min}$ for at least $1 \mathrm{~h}$ to stabilize brain tissue from the probe-induced trauma. Dialysate tubes were pre-filled with $5 \mu$ l of $0.5 \mathrm{M}$ perchloric acid and dialysates were assayed at 10 -min time intervals. DA was assayed using HPLC with electrochemical detection. The HPLC system consisted of a dual piston pump (Model 582 Solvent Delivery System; ESA, Chelmsford, Mass., USA), an autosampler with a cooling tray (Model 542; ESA), an MD-150 column $(3 \times 150 \mathrm{~mm}$; $3 \mu \mathrm{m}$, ESA), and an ESA 5200A CoulArray detector with an ESA 5014B dual-electrode analytical cell. The first electrode was set at $-150 \mathrm{mV}$, and the second at $+200 \mathrm{mV}$. The mobile phase delivered at $0.6 \mathrm{ml} / \mathrm{min}$ was MD-TM $(75 \mathrm{mM}$ sodium dihydrogen phosphate, $1.7 \mathrm{mM}$ 1-octanesulfonic acid, $0.73 \mathrm{~mm}$ triethylamine, $25 \mu \mathrm{M}$ EDTA, and 10\% acetonitrile at $\mathrm{pH} 3.0$ adjusted with phosphoric acid). Under these conditions, the limit of sensitivity for DA standards $(\mathrm{S} / \mathrm{N}=3)$ is about $0.2 \mathrm{fM}$. The experimental protocol, including halothane anesthesia, was similar to the phMRI study above. Three baseline dialysates were collected before the bolus administration of cocaine $(0.5 \mathrm{mg} / \mathrm{kg}$ i.v. $)$, followed by 9 after drug dialysates (90 min).
Statistics for META Analysis

For the meta-analysis, we pooled data at each time point from the various studies that reported both adult and young values. We used a one-way ANOVA with a Tukey HSD post-hoc correction for multiple comparisons as a function of age with ages binned to within the closest week to examine the effects of age for behavior, ligand binding and mRNA expression levels. We further used an unpaired t test to compare a given parameter (e.g. ligand binding) between groups at a fixed age interval such as 20-30 days of age. Further details are provided in Results.

\section{Results}

Vascular Response to $\mathrm{CO}_{2}$ Is Functional at P22

Since phMRI assesses the neuronal activity via a hemodynamic response, it is important to test if the juvenile brain has a comparable vascular response to the adult brain. A hypercapnia study was performed to answer such a question. At baseline, rats were mechanically ventilated with a mixture of air and oxygen (1:1). Hypercapnia was induced by mixing in $7.5 \% \mathrm{CO}_{2}$ for $10 \mathrm{~min}$ and then switching back to the basal air mixture. Hypercapnia induced an rCBV increase with similar responses in both age groups (fig. 2) with strongest rCBV increases in the thalamus, followed by the $\mathrm{CPu}$ and cortex. The hypercapnia study indicates that the vascular response to $\mathrm{CO}_{2}$ is functional at $\mathrm{P} 22$.

\section{rCBV Response to DA Ligands}

Using phMRI, we studied the brain response to $\mathrm{AMPH}, \mathrm{MPH}$, cocaine, DHDD, and quinpirole at juvenile and adult ages. Figure 3 shows the average/peak rCBV response, masked by a map of the $p$ values (GLM, $\mathrm{p}<10^{-10}$ ) for the corresponding drug. Figure 4 shows the rCBV time courses from the CPu. Table 1 summarizes the $\mathrm{rCBV}$ response using ROI analysis for all drugs.

Cocaine. For adults, cocaine challenge $(0.5 \mathrm{mg} / \mathrm{kg}$ i.v. $)$ induced biphasic rCBV changes (negative followed by positive rCBV changes) in adult rats (fig. 4a). This same dose of cocaine in $\mathrm{P} 22$ rats induced a long rCBV decrease without reversing to positive $\mathrm{rCBV}$ as seen in the adults. The map of the average rCBV change $0-10$ min after cocaine challenge (fig. 3a) was dominated by the rCBV increase in adult rats and was dominated by an rCBV decrease in $\mathrm{P} 22$ rats. Using microdialysis, we found that cocaine led to significant $\mathrm{DA}$ increases in $\mathrm{CPu}$ in both age groups (P22, $n=4$; adults, $n=5)$. The basal DA levels we measured were $2.23 \pm 1.2 \mathrm{nM}$ in the adults and $2.07 \pm$ $1.0 \mathrm{nM}$ in the P22 animals. However, the degree of DA efflux following cocaine administration was smaller in the 


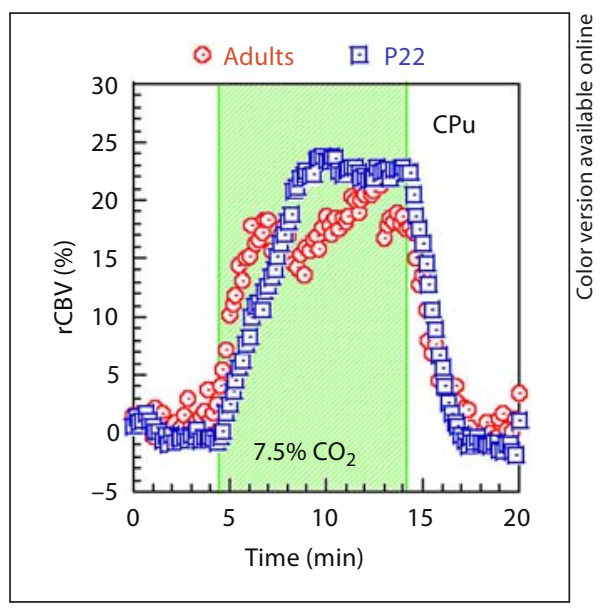

Fig. 2. Response to hypercapnia challenge in young and adult animals. Data shown represent changes in $\mathrm{CBV}$ for a $7.5 \% \mathrm{CO}_{2}$ challenge which occurs during the shaded interval. The data come from the $\mathrm{CPu}$ and indicate that there is little difference in vascular response between the two groups.

P22 rats (fig. 5a). The microdialysis data indicates that the absence of rCBV increases in P22 rats was not due to impairment of DA efflux.

We compared the DA efflux with data from prior autoradiographic analysis of the maturation of DAT binding [Coulter et al., 1996; Galineau et al., 2004] (fig. 5b). These data suggest that fully functional DAT binding is not $100 \%$ complete until about 45 days of age, corresponding to the fact that we saw less effect of cocaine on DA efflux in the P22 animals.

Methylphenidate. MPH (2 mg/kg i.v.) challenge led to significant $\mathrm{rCBV}$ increases in the frontal cortex and $\mathrm{CPu}$ in adult rats. The rCBV time course of the adult group shows positive values in all regions except the nucleus accumbens. In young rats, the same dose of MPH led to negative $\mathrm{rCBV}$ in the $\mathrm{CPu}$, nucleus accumbens, and the posterior cingulate cortex, and induced no rCBV changes in the frontal cortex. The dramatic opposite rCBV responses to MPH challenge in juvenile and adult rats are apparent in the rCBV maps (fig. 3b) and time courses (fig. 4b). The average rCBV changes over 20 min after $\mathrm{MPH}$ challenge using ROI analysis (without statistical threshold) are shown in table 1.

$D$-Amphetamine. In contrast to the pattern noted with cocaine and MPH, AMPH (1 mg/kg i.v.) induced significant $\mathrm{rCBV}$ increases in both age groups (fig. $3 \mathrm{c}$ and $4 \mathrm{c}$ ). However, the degree of rCBV response to AMPH did not cover as many brain regions and was not as strong in P22
Table 1. Average rCBV responses in major brain areas

\begin{tabular}{|c|c|c|}
\hline Cocaine $(0-10 \mathrm{~min})$ & Adult $(n=5)$ & Young $(\mathrm{n}=8)$ \\
\hline $\mathrm{CPu}$ & $6.49 \pm 1.26$ & $-2.93 \pm 0.58^{*}$ \\
\hline $\mathrm{mPFC}$ & $5.00 \pm 1.48$ & $-1.92 \pm 0.74^{*}$ \\
\hline NAc & $-2.56 \pm 0.59$ & $0.87 \pm 1.77$ \\
\hline Thalamus & $10.09 \pm 1.16$ & $0.99 \pm 0.76^{*}$ \\
\hline M1 & $7.18 \pm 1.36$ & $-1.03 \pm 0.78^{*}$ \\
\hline M2 & $4.20 \pm 0.78$ & $-0.82 \pm 0.79^{*}$ \\
\hline $\mathrm{S} 1$ & $4.02 \pm 1.10$ & $-1.52 \pm 0.74^{*}$ \\
\hline $\mathrm{S} 2$ & $2.60 \pm 0.62$ & $-0.42 \pm 1.36$ \\
\hline MPH (0-20 min) & Adult $(\mathrm{n}=4)$ & Young $(n=5)$ \\
\hline $\mathrm{CPu}$ & $4.62 \pm 1.12$ & $-5.50 \pm 1.96^{*}$ \\
\hline $\mathrm{mPFC}$ & $2.98 \pm 1.38$ & $-3.07 \pm 1.85^{*}$ \\
\hline NAc & $-3.30 \pm 0.31$ & $-8.50 \pm 2.09$ \\
\hline Thalamus & $7.31 \pm 2.24$ & $0.76 \pm 2.65$ \\
\hline M1 & $5.91 \pm 1.17$ & $-2.04 \pm 2.00^{*}$ \\
\hline M2 & $4.52 \pm 1.21$ & $-3.12 \pm 2.03^{*}$ \\
\hline S1 & $5.50 \pm 1.23$ & $-3.68 \pm 2.10^{*}$ \\
\hline $\mathrm{S} 2$ & $6.60 \pm 1.55$ & $-3.84 \pm 2.46^{*}$ \\
\hline АMPH (0-50 min) & Adult $(\mathrm{n}=5)$ & Young $(\mathrm{n}=3)$ \\
\hline $\mathrm{CPu}$ & $16.85 \pm 4.56$ & $13.01 \pm 2.85$ \\
\hline mPFC & $3.93 \pm 5.79$ & $3.39 \pm 0.70$ \\
\hline NAc & $12.24 \pm 7.19$ & $20.29 \pm 6.10$ \\
\hline Thalamus & $6.99 \pm 3.22$ & $16.57 \pm 2.88$ \\
\hline M1 & $4.24 \pm 3.37$ & $2.77 \pm 3.10$ \\
\hline M2 & $2.91 \pm 3.88$ & $3.91 \pm 2.62$ \\
\hline S1 & $2.82 \pm 2.20$ & $5.67 \pm 2.92$ \\
\hline $\mathrm{S} 2$ & $16.7 \pm 2.46$ & $7.11 \pm 3.44$ \\
\hline DHDD (0-50 min) & Adult $(\mathrm{n}=4)$ & Young $(n=6)$ \\
\hline $\mathrm{CPu}$ & $11.57 \pm 5.17$ & $-2.49 \pm 2.48^{*}$ \\
\hline $\mathrm{mPFC}$ & $8.67 \pm 3.84$ & $-2.18 \pm 2.76^{*}$ \\
\hline NAc & $8.36 \pm 3.66$ & $6.97 \pm 3.76$ \\
\hline Thalamus & $19.39 \pm 8.80$ & $3.02 \pm 2.90^{*}$ \\
\hline M1 & $7.07 \pm 3.51$ & $-0.94 \pm 2.04^{*}$ \\
\hline M2 & $4.82 \pm 1.45$ & $-1.51 \pm 2.26^{*}$ \\
\hline $\mathrm{S} 1$ & $8.18 \pm 5.44$ & $6.07 \pm 4.00$ \\
\hline $\mathrm{S} 2$ & $9.89 \pm 5.98$ & $5.27 \pm 6.96$ \\
\hline Quinpirole (0-40 min) & Adult $(\mathrm{n}=7)$ & Young $(\mathrm{n}=4)$ \\
\hline $\mathrm{CPu}$ & $-8.99 \pm 1.94$ & $-9.53 \pm 2.76$ \\
\hline $\mathrm{mPFC}$ & $-11.26 \pm 3.72$ & $-5.16 \pm 2.33$ \\
\hline NAc & $-5.01 \pm 3.46$ & $-4.26 \pm 5.99$ \\
\hline Thalamus & $-6.33 \pm 4.26$ & $-4.52 \pm 5.31$ \\
\hline M1 & $-2.91 \pm 2.73$ & $-4.36 \pm 2.21$ \\
\hline M2 & $-8.25 \pm 2.25$ & $-1.90 \pm 2.42^{*}$ \\
\hline S1 & $-2.18 \pm 2.49$ & $-5.47 \pm 2.15$ \\
\hline $\mathrm{S} 2$ & $-0.89 \pm 2.03$ & $-4.00 \pm 2.38$ \\
\hline
\end{tabular}

${ }^{*} \mathrm{p}<0.05$ vs. adults. 
Young

Adults

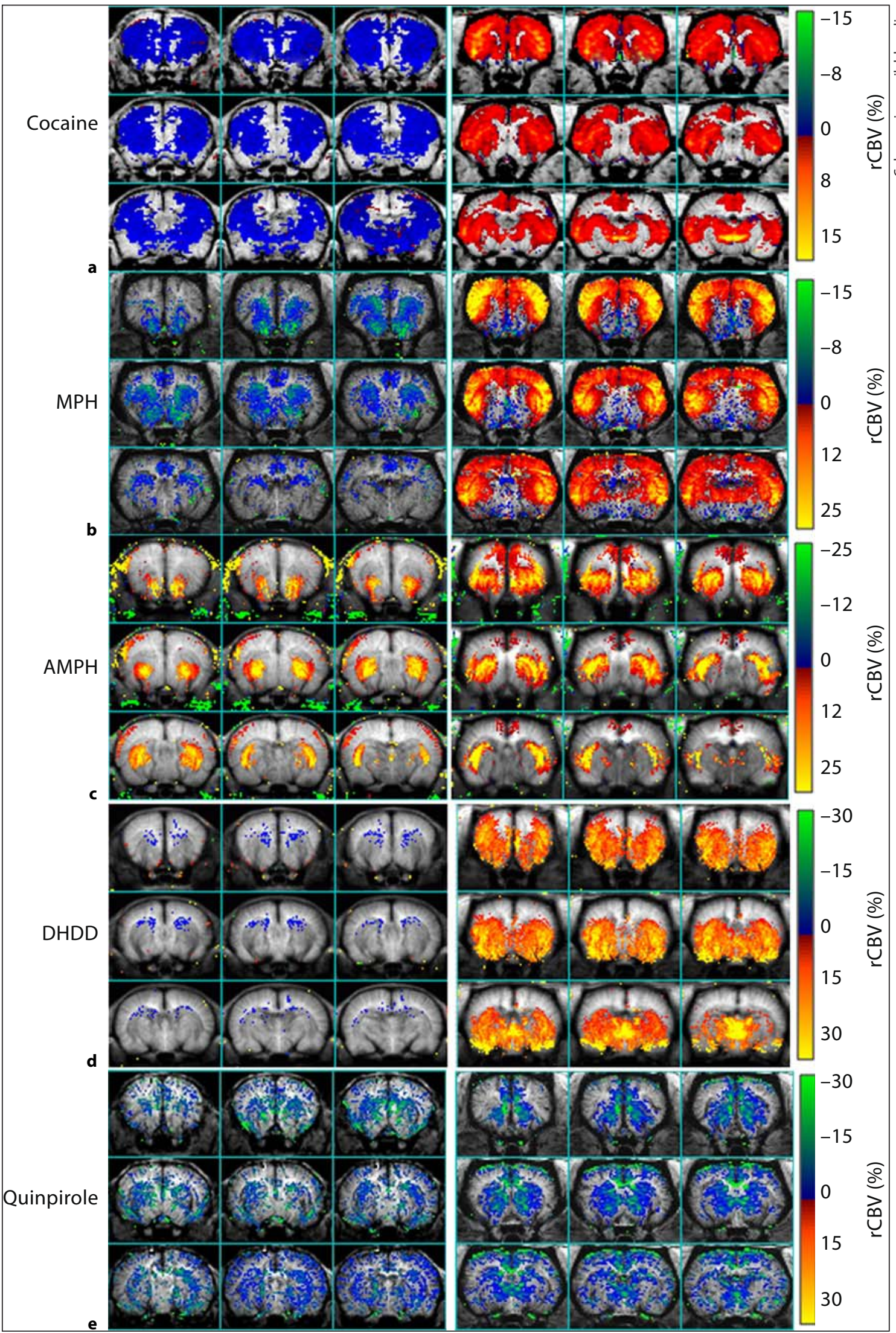


rats compared to adults. In particular, much of the cortical activation seen in the adults is missing in the young rats. The average rCBV changes over $50 \mathrm{~min}$ after $\mathrm{AMPH}$ challenge using ROI analysis (without statistical threshold) are shown in table 1.

DHDD - Selective D1/D5 Agonist. DHDD (3 mg/kg i.v.) induced a significant $\mathrm{rCBV}$ increase in adult rats with a map similar to that of the DAT ligands (fig. $3 \mathrm{~d}$ ). The robust $\mathrm{rCBV}$ response seen in the adults was almost completely absent in all regions of the young brain (fig. $4 \mathrm{~d}$ ), demonstrating a hypo-responsiveness to D1/D5 agonism in the young rats.

Quinpirole - Selective D2/D3 Agonist. Quinpirole ( $2 \mathrm{mg} / \mathrm{kg}$ i.v.) induced a negative $\mathrm{rCBV}$ response in both young animals and adults. The maps in the 2 age groups were quite similar, as were the rCBV amplitudes (fig. 3e; table 1).

\section{Meta-Analysis of Literature Data}

Numerous studies have been conducted over the past 30 years detailing changes in DA receptor subtypes as a function of brain maturation. A wide range of techniques and drugs have been used to assay mRNA levels, ligand binding, and behavioral effects in response to dopaminergic drugs. Furthermore, it is clear that, even after taking into consideration differences in techniques and ligands, not all the studies agree as to the direction of the maturational changes. We therefore performed a restricted meta-analysis of the existing data to understand the relation between these other variables and the phMRI results we observed. Due to the old age of most of the stud-

Fig. 3. Averaged maps comparing the CBV response to various dopaminergic ligands in young (left panels) and adult (right panels) animals. a Response to a $0.5 \mathrm{mg} / \mathrm{kg}$ cocaine challenge demonstrating opposite signs (negative or positive) across almost all brain regions for the young $(n=8)$ and adult $(n=5)$ animals. Every animal in each group showed the same sign for CBV changes. b Response to $2 \mathrm{mg} / \mathrm{kg}$ MPH challenge in young $(\mathrm{n}=5)$ and adult $(n=4)$ animals. Similar to cocaine, every animal in each group showed the same sign for the CBV change. c Response to a $1 \mathrm{mg} /$ $\mathrm{kg}$ AMPH challenge. Both the young $(\mathrm{n}=3)$ and adult $(\mathrm{n}=5)$ animals had primarily positive CBV responses. Note that this dose of AMPH produces much larger increases in extra-synaptic DA than the doses used for cocaine or MPH. $\mathbf{d}$ Response of young $(\mathrm{n}=6)$ and adult $(\mathrm{n}=4)$ animals to $3 \mathrm{mg} / \mathrm{kg}$ of the selective D1 agonist dihydrexidine. There is little response to the drug in the young animals whereas the adult animals show a large CBV increase. e Response of young $(n=4)$ and adult $(n=7)$ animals to quinpirole $2 \mathrm{mg} / \mathrm{kg}$ i.v. The response in the young and adult animals is essentially identical with both groups showing robust negative CBV changes.

phMRI of DA Receptor Ontogeny ies, it was impossible to obtain the original data, so the average data was extracted from tables and figures in the papers. Therefore, this restricts the total number of subjects, but otherwise, for some of the variables, produces a consensus picture of the state of the data. We only included studies where adult values were recorded or described. For the purposes of the analysis, adult data were defined as $\geq 60$ days postnatal age, though no animals older than P90 were included to control for any effects of aging. We included mRNA expression levels, ligand binding, and locomotor response to D1 and D2 agonists, as well as locomotor and grooming responses to cocaine. In young animals, grooming seems to be an indicator of D1 function, while locomotor activity is more strongly driven by $\mathrm{D} 2$ function. The data were all normalized to the adult value at $60-90$ days representing $100 \%$. The binding and mRNA data were taken only from the $\mathrm{CPu}$. In figure $6 \mathrm{a}$, the percent of ligand binding for either D1 or D2 receptors is compared to adult [Murrin and Zeng, 1986; Zeng et al., 1988; Gelbard et al., 1989; Sales et al., 1989; Murrin and Zeng, 1990; Rao et al., 1991; Crawford et al., 1994; Schambra et al., 1994; Flores et al., 1996; Jung and Bennett, 1996; Johansson et al., 1997; Stanwood et al., 1997; du Bois et al., 2008]. In general, there is an increase in $\mathrm{D} 1$ and $\mathrm{D} 2$ receptor binding as the animal grows, with little difference between the D1 and D2 curves. There was a highly significant effect of age for both D1 and D2. Binning the data into groups evenly spaced between 1.5 and 6.5 weeks showed an effect of age for D1 binding $\left(\mathrm{F}_{46,4}=\right.$ 7.57, $\mathrm{p}<0.002)$ and for $\mathrm{D} 2$ binding $\left(\mathrm{F}_{45,4}=14.9\right.$; $\mathrm{p}<$ $0.0001)$ and a small difference between the D1 and D2 curves at the ages 10-20 days (fitting to a logistic equation showed the $\mathrm{EC}_{50}$ to be $10.6 \pm 1.3$ days for $\mathrm{D} 2$ and $5.6 \pm$ 1.4 days for D1 - in either case both those values are considerably lower than the ages we studied). At 20-30 days of age there was no difference between D1 and D2 binding $(\mathrm{D} 1=101.9 \pm 10.3$ and $\mathrm{D} 2=86.8 \pm 6.6$ as percent of adult; $p=0.23$ unpaired $t$ test). A few papers showed higher values in animals at around P35-45, which then decrease in adulthood, but the data here are under-powered to conclusively show such an effect. In figure $6 \mathrm{~b}$ the mRNA expression levels are shown [Chen and Weiss, 1991; Creese et al., 1992; Guennoun and Bloch, 1992; Moody and Spear, 1992a; Srivastava et al., 1992; Weiss et al., 1992; Schambra et al., 1994; Filloux et al., 1996; Flores et al., 1996; Jung and Bennett, 1996]. The pattern with regards to the D1 and D2 seems quite different at the early ages $(<\mathrm{P} 10-$ although most of the high points for $\mathrm{D} 1$ mRNA come from a single paper), but converge on the adult values after P10. There was a significant effect of age

Dev Neurosci 2010;32:125-138 
Fig. 4. Averaged time courses of $\mathrm{CBV}$ changes in $\mathrm{CPu}$ induced by the various drugs: $0.5 \mathrm{mg} / \mathrm{kg}$ cocaine (a); $2 \mathrm{mg} / \mathrm{kg}$ $\mathrm{MPH}$ (b); $1 \mathrm{mg} / \mathrm{kg}$ AMPH (c); $3 \mathrm{mg} / \mathrm{kg}$ $\operatorname{DHDD}(\mathbf{d})$.
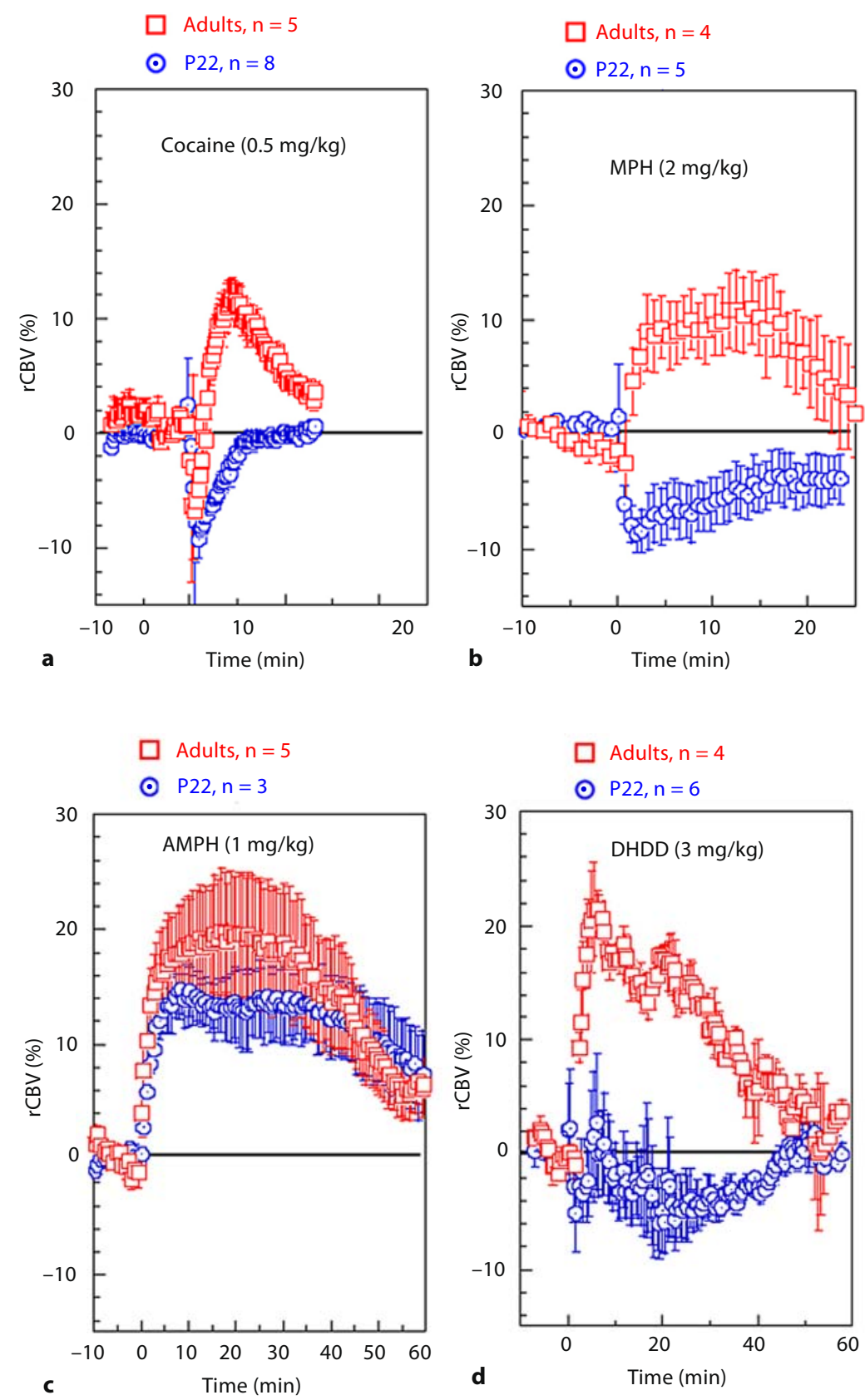

on D2 mRNA expression $\left(\mathrm{F}_{32,4}=2.78 ; \mathrm{p}<0.05\right)$, but the effect of age on D1 mRNA expression was marginally significant (albeit with fewer studies; $\mathrm{F}_{20,4}=2.24 ; \mathrm{p}=0.1$ ). Between 10 and 30 days of age, D2 and D1 mRNA expression levels as a fraction of adult values were essentially identical (fig. 6b). We further compared locomotor data in response to D1 and D2 agonists (fig. 6c) [Spear and Brake, 1983; McDougall et al., 1990; McDougall et al., 1992; Moody and Spear, 1992a, b; Lin and Walters, 1994; Van Hartesveldt et al., 1994; Frantz and Van Hartesveldt, 1999]. There appears to be a large increase in locomotor activity in response to D2 agonists between P14 and P30, 
Fig. 5. Effects of age on DA efflux and DAT binding. a Microdialysis data showing increases in extracellular DA after $0.5 \mathrm{mg} / \mathrm{kg}$ cocaine challenge in young and adult animals. The basal DA levels we measured were $2.23 \pm 1.2 \mathrm{nM}$ in the adults and 2.07 $\pm 1.0 \mathrm{nM}$ in the P22 animals. The young animals show a diminished, but still robust, response to cocaine. b Data taken from 2 studies [Coulter et al., 1996; Galineau et al., 2004] measuring changes in DAT binding as a function of postnatal age. The adult levels are reached by about P20 indicating that the differences we observe are not reflective of decreased DAT.

Fig. 6. Results of meta-analyses of changes in various DA receptor parameters as a function of age. Studies were included where both adult and young data were measured in the same study. a Plots of changes in D1 and D2 binding as a fraction of the adult values; fits to a logistic equation are also shown. The data show small differences in binding between D1 and D2 as a function of age. Between ages P20 and P30 there were no significant differences between D1 and D2. b Effects of age on mRNA expression of D1 and D2 receptors. For both D1 and D2, the values approach the adult values after about P10. Lines shown are smoothed interpolations to guide the eye. c Effects of D1 ad D2 agonists on locomotor behavior as a function of age. The D2 response shows a peak at about P20. The D1 response is essentially flat, but we could only find 2 studies reporting data in both young and adult animals. d Locomotor response to cocaine as a function of age. Similar to the D2 agonist data in $\mathbf{c}$ there is a peak response between P20 and P30.
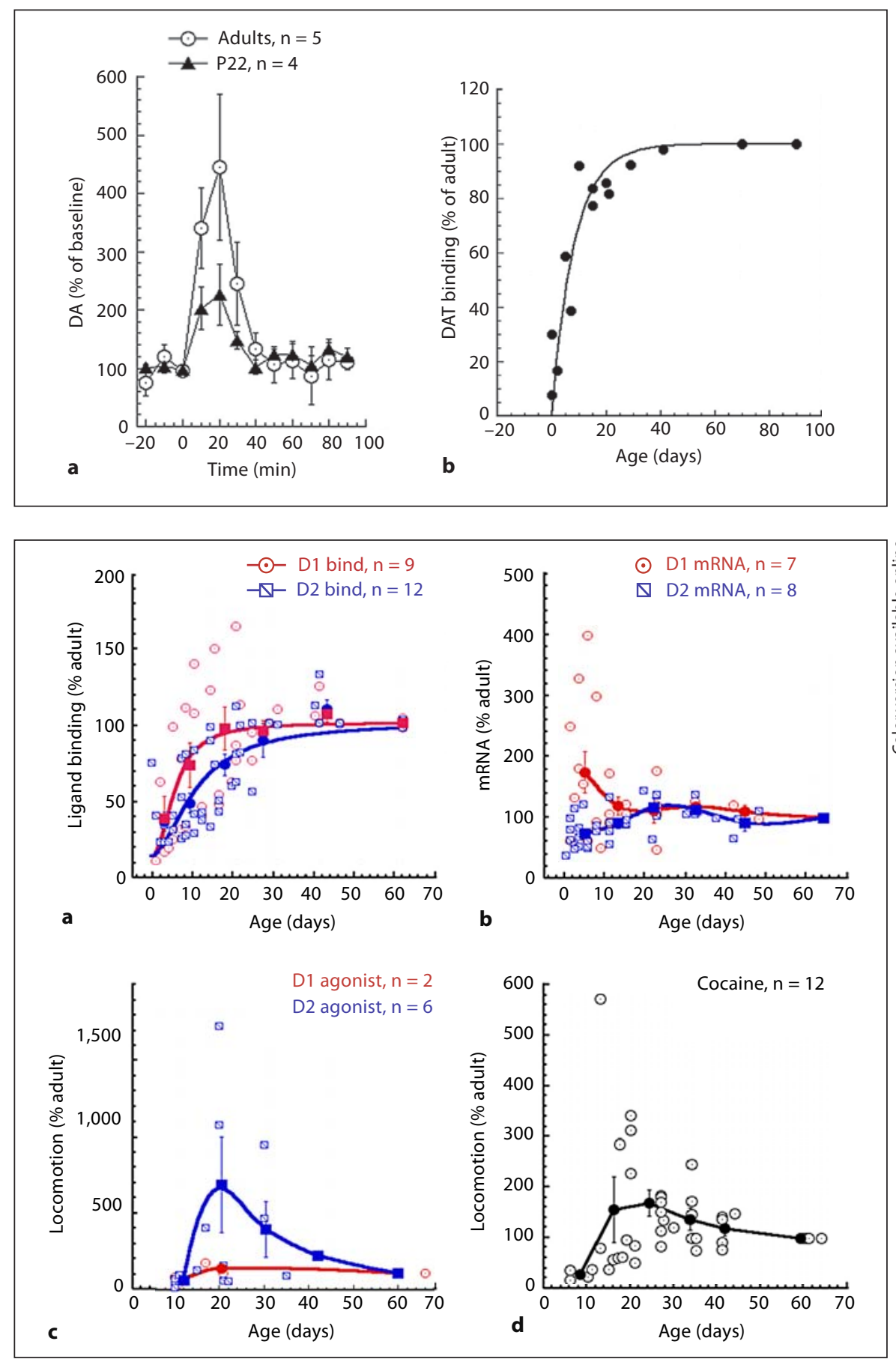

which then decreases sharply to the adult level. The locomotor response to the D1 agonist showed no such pattern, although we could only find 2 studies that had tested this. One paper showed that adult animals showed a much larger grooming response to D1 agonist challenge than rats at $\mathrm{P} 17$, but that the $\mathrm{P} 17$ rats could be driven to an adult-like response using a very high dose of D1 agonist [McDougall et al., 1990]. This suggests, similar to our phMRI findings, that there is a hypo-functionality of the D1R function at these ages. Nonetheless, the data suggest a hyper-responsivity to D2 agonists compared to D1 agonists between P14 and P35. We further compared the pat- 
tern of locomotor response to cocaine as a function of age. Similar to what is seen with the D2 agonists, there is an increase as the animals approach 20-35 days of age and then a decrease to the adult values (fig. 6d) [Spear and Brake, 1983; Collins and Izenwasser, 2004; Caster et al., 2005, 2007; Catlow and Kirstein, 2005, 2007; Frantz et al., 2007; Badanich et al., 2008; Parylak et al., 2008; Smith and Morrell, 2008]. These data support a D2 over D1 predominance in locomotion and possibly mRNA at the time periods where we see negative $\mathrm{rCBV}$ responses to cocaine or $\mathrm{MPH}$, indicating the functional predominance of the D2 effects.

\section{Discussion}

There is no doubt that there are profound developmental changes in the dopaminergic system as a function of aging. Based upon the meta-analysis presented above, it is clear that both mRNA expression and autoradiographic ligand-binding data show highly significant changes from P0 to P40 (fig. 6). Our phMRI data as well show profound differences between the animals at P2030 and adults. The most remarkable finding is the reversal of rCBV changes after either cocaine or MPH challenge. Based upon our prior studies using D1 and D2 agonists [Chen et al., 2005; Choi et al., 2006], negative rCBV responses can be interpreted as reflecting agonism of D2/ D3 receptors, whereas positive $\mathrm{CBBV}$ changes are associated with agonism of D1/D5 receptors. Thus, these data suggest that the animals between the ages of P20 and P30 show a hypo-responsivity of D1-like function over D2like function in this age regime. This conclusion is bolstered by the phMRI data with the D1 agonists showing huge positive changes in the adults and little response in the young animals, whereas the D2 agonist showed similar negative changes in both age groups.

These observations are consistent with the behavioral profiles of locomotor activity induced by D1 or D2 agonists as well as cocaine. Prior studies show that D2 agonists show a peak in induction of locomotor activity between P20 and P30 (the same age of animals we studied; fig. $6 c$ ) that is not paralleled by D1 agonists. Examination of D1 agonists dose effects by McDougall et al. [1990] showed that high doses of D1 agonist induced adult-like grooming behavior, whereas lower doses produced little grooming activity. This finding is reflected in our data showing that $3 \mathrm{mg} / \mathrm{kg}$ amphetamine, which induces a huge increase in DA concentrations, produces D1-like rCBV responses in both young and adult animals.
Moreover, lower doses of amphetamine in adults can produce a profile matching D2-like CBV responses more closely, which becomes D1-like at higher doses [Ren et al., 2009]. The cocaine-induced locomotor behavioral profile shows a similar peak at these ages. While there is some agreement that at these ages D1 agonism induces more grooming than locomotor activity, the magnitude of the grooming behavior does not show such a steep age-dependent profile as the D2-induced locomotor activity [Moody and Spear, 1992a, b].

There is evidence in the literature for the development of D2 autoreceptor functionality during this age range [Andersen and Gazzara, 1994; Van Hartesveldt et al., 1994]. Behaviorally, it has been shown that agonizing D2R (via the D2 agonist quinpirole) induced different patterns of locomotor activity (suppressing or increasing travel distance) in rats at different ages [Frantz and Van Hartesveldt, 1999]. Quinpirole has higher receptor affinity to the presynaptic autoreceptor over the postsynaptic D2R at low doses [Schoemaker et al., 1997]. However, little is known about the density changes of autoreceptor versus postsynaptic D2R as a function of age, nor about the changes in receptor affinity to these 2 populations. A number of papers presented above, forming the basis of the meta-analysis, suggest that autoreceptor function starts to fully develop at about 20 days of age [Spear and Brake, 1983; McDougall et al., 1990; Lin and Walters, 1994; Van Hartesveldt et al., 1994; Frantz et al., 1996; Bowman et al., 1997]. Our results show a smaller increase in extracellular DA induced by cocaine in the young animals compared to the older animals. Since the D2 autoreceptors, as well as D3 receptors, have a higher affinity for DA than the postsynaptic D2 receptors, this will likely lead to more D2-like rCBV responses compared to the higher amounts of DA efflux seen in adults [Chen et al., 2005]. There could also be some effect of incomplete development of the DAT at P22 [Coulter et al., 1996; Galineau et al., 2004].

The $\mathrm{D} 2$ agonism induced by quinpirole also competes with the D1R agonism induced by endogenous DA. The age-dependent locomotor response to D2 agonist may be due to a change in the ratio of D1R and D2R expression as the animal ages. Since no evidence shows that D1R and D2R have equal functional influence in DA signaling (i.e. that the postsynaptic influence of a single DA binding to $\mathrm{D} 1 \mathrm{R}$ or $\mathrm{D} 2 \mathrm{R}$ is equal but in the opposite direction), a slight shift of the ratio between D1R and D2R density may alter the postsynaptic status dramatically. phMRI measures dopaminergic function as a whole including contributions of the synaptic DA concentration, the vascular 
profile of DA receptors [Choi et al., 2006], neuronal activity evoked by D1R and D2R, and their impacts on other neurotransmitters as well as the downstream signaling pathways. Although it is not easy to dissect the individual contributions, use of different pharmacological agents targeting different receptor subtypes can help to gather information on the functional changes as the brain develops. We therefore used a variety of pharmacological agents to increase the synaptic DA concentration in the mesoaccumbens and the mesocortical pathways: AMPH by releasing DA [Sulzer et al., 2005], and cocaine and MPH by blocking DAT.

In order to obtain the complete behavioral repertoire in response to dopaminergic agonism, it is usually assumed that one needs stimulation of both D1 and D2 receptors. However, at the early ages there appears to be more of a dichotomy in that D2 agonism leads to much more locomotor activity than D1 agonism (except at very high doses of D1 agonist [McDougall et al., 1992]). Likewise, $\mathrm{D} 1$ agonism leads to much greater grooming behavior than D2 agonism, with the latter even inhibiting grooming activity. The absolute magnitude of the locomotor behaviors, as measured by metrics such as beam crossings, is much greater than the counts of grooming activity, thus suggesting more powerful effects of D2-like behaviors than D1-like behaviors in the young rats - i.e. the total amount of motor activity is greater. These data also suggest that the locomotor profile of cocaine as a function of aging (fig. $6 \mathrm{~d}$ ) is primarily driven by the D2R.

In adult rats, the relatively large $\mathrm{rCBV}$ increases induced by DA releaser (AMPH) and DAT blockers (cocaine and $\mathrm{MPH}$ ) [data from this paper and Marota et al., 2000; Mandeville et al., 2001; Mandeville et al., 2004] indicates a strong action of D1R. This is based on our previous phMRI results that agonizing D1-like receptors led to rCBV increase and agonizing D2-like receptors led to rCBV decreases [Chen et al., 2005; Choi et al., 2006]. Further, D1 antagonism blocks the response to cocaine [Marota et al., 2000], as well as the DAT blocker CFT or amphetamine in adult animals and D1 antagonism does not affect DA efflux [Choi et al., 2006]. However, in the young rats, the increased synaptic DA concentration either led to a reduced $\mathrm{rCBV}$ increase (by AMPH) or rCBV decreases (by cocaine and MPH). In adult rats in the striatum, the D1 receptor accounts for an average of $78 \%$ of the total DA receptors, but with only $20 \%$ of D1R at the high affinity state [Richfield et al., 1989]. The D2R accounts for the remaining $22 \%$ of DA receptors but the majority of $\mathrm{D} 2 \mathrm{R}$ is at the high affinity state $(>80 \%)$ [Richfield et al., 1989]. It thus was suggested that a portion of the D1R serves as spare receptors [Richfield et al., 1989]. The copious amount of DA induced by AMPH/cocaine/MPH may thus bind to the spare D1R and induce an $\mathrm{rCBV}$ increase in the adult rats. In young rats, the relative populations of $\mathrm{D} 1 \mathrm{R}$ and $\mathrm{D} 2 \mathrm{R}$ and the proportion of each receptor at its high affinity state are not clear. Studies using quantitative autoradiography in rodents and primates showed that there was an initial overproduction followed by a declination of the dopamine D1R and D2R during adolescence [Montague et al., 1999; Andersen et al., 2000], although little evidence indicates that these two ontogenic processes are in synchrony. The rCBV decreases to cocaine and MPH challenge suggests that, at young ages, extracellular DA binds more efficiently to D2R than D1R. Since AMPH not only occupies (and blocks) the DAT binding site (similar to cocaine or MPH), but also enhances DA efflux, the dose of AMPH we used leads to much greater synaptic DA concentrations than similar doses of cocaine or MPH [Sulzer et al., 2005]. Microdialysis studies in adult rats using pharmacological doses similar to our study found the degree of DA efflux is: AMPH $>1,000 \%$, cocaine 300\%, MPH $\sim 450 \%$ of the baseline level [Butcher et al., 1991; Feigenbaum and Howard, 1997; Ito et al., 2002; Porras et al., 2003; Schwarz et al., 2004]. The extra amount of DA released by AMPH increases the likelihood of D1R binding, and is reflected in the rCBV increase in the young rats.

The ROI we defined as the nucleus accumbens also includes the islets of Calleja. The Islets of Calleja and nucleus accumbens have high D3 receptor density and the D3 density is much higher in the accumbens than in the $\mathrm{CPu}$. Agonism of $\mathrm{D} 3$ receptors leads to negative CBV changes [Choi et al., 2006]. Therefore, the balance between the positive and negative CBV changes is skewed towards negative changes at low DA concentrations since at these concentrations there will be higher relative occupancy of the D3R since the D3R has much higher affinity for DA than the D1R. Further, D2 autoreceptors, whose agonism leads to decreased DA release, also have higher affinity for D2 than postsynaptic D1R. The high dose of amphetamine used $(1 \mathrm{mg} / \mathrm{kg})$ produces a much larger increase in synaptic DA (about 1,300\%); therefore, there is a much more D1-like effect for amphetamine.

We saw large activation of the thalamus in the adults, but not the young rats. The thalamus is part of the striatal output circuitry, and therefore its response may entail other mediators of CBV than solely DA. The thalamus has high enrichment in D5 receptors, which we showed to very densely label microvessels in the thalamus [Choi et al., 2006]. D5R have a much higher affinity for DA than 
D1R [Cooper et al., 1996]. Therefore, there may be a more positive response to a relatively lower concentration of DA. Evidence of this is supported by the results with DHDD (a D1/D5 agonist) where there are huge changes in the thalamus in adults similar to those we have observed with other D1 agonists [Choi et al., 2006]. The CPu has a large D2 density in addition to D1. Since D2 agonism produces negative $\mathrm{CBV}$ changes this will lower the overall CBV change.

The relatively hypoactivity of D1R was further tested by challenging young and adult rats with the highly selective D1 agonist DHDD. In the adult rats, DHDD led to significant $\mathrm{rCBV}$ increases in the brain. Other D1 agonists also produce large CBV increases [Choi et al., 2006]. We expected that DHDD would lead to a robust, but smaller, increase in $\mathrm{rCBV}$ in the juvenile rats. However, the juvenile brain was almost completely non-responsive to the DHDD. This finding suggests that the majority of D1R at young ages may not be fully functional with regards to postsynaptic signaling. It would thus appear that very high doses of D1 agonist or very high DA concentrations are required to reflect the D1 functionality and, when challenged with cocaine or MPH, we primarily observe $\mathrm{D} 2 \mathrm{R}$ functionality. The functionality of $\mathrm{D} 2 \mathrm{R}$ at a young age was validated by our quinpirole study showing similar rCBV decreases at young and old ages. The CBV map we observed with cocaine or MPH challenge in the juvenile animals here is very similar to that which we observed with quinpirole (fig. 4e) [Chen et al., 2005] and norpropylapomorphine, a D2 agonist, in adult rats, [Choi et al., 2006]. Future studies will further need to characterize the ontogeny of the DA receptors on the microvasculature. We showed that D1 and D5 receptors are on brain microvessels, such as capillaries and arterioles, whereas D3 receptors were found on astrocytes [Choi et al., 2006]. Therefore, it may also be the case that the D1 and D5 microvessel receptors are not fully mature between P20 and P30.
The results of this study suggest that the full behavioral response to psychostimulants such as cocaine are not fully developed in young animals. This manifests as a hypofunctionality of D1 receptors. Given the important roles of $\mathrm{D} 1$ receptors in frontal regions in many aspects of memory and cognition, including impulse inhibition [McNab et al., 2009], our data suggest that this hypofunctionality may increase sensitivity to psychostimulants. A recent study showed that there was increased D1 functionality in adults compared to juveniles, and that prenatal cocaine exposure had a profound effect on D1R [Tropea et al., 2008].

To summarize our results, we found that there is a hypo-functionality of D1 compared to D2 as measured using MRI in young animals. It is increasingly clear that both D1 and D2 receptors operate and couple to G proteins as dimers or oligomers [Strange, 2005; Vivo et al., 2006]. Full functionality of these receptors is also importantly linked to cell surface trafficking [Wurch et al., 2001; Ferone et al., 2007]. How these processes may change during the maturation of the dopaminergic system remains to be studied. Understanding such developmental processes is crucial to more fully understanding the differential effects of psychostimulants on children and, as well, understanding how dysfunctions of these processes may lead to psychiatric illnesses.

\section{Acknowledgments}

Dr. Young Kim synthesized and provided the contrast agent MION. John Moore conducted the surgical preparation for MRI studies. This study was supported by the National Institute of Health (National Centre for Complementary and Alternative Medicine) PO1 AT002048, 1R21AT004455-01A2, and National Institute on Drug Abuse 5R01 DA16187-05

\section{References}

-Andersen SL, Gazzara RA (1994): The development of D2 autoreceptor-mediated modulation of $\mathrm{K}(+)$-evoked dopamine release in the neostriatum. Brain Res Dev Brain Res 78: $123-130$.

Andersen SL, Navalta CP (2004): Altering the course of neurodevelopment: a framework for understanding the enduring effects of psychotropic drugs. Int J Dev Neurosci 22: 423-440.
Andersen SL, Thompson AT, Rutstein M, Hostetter JC, Teicher MH (2000): Dopamine receptor pruning in prefrontal cortex during the periadolescent period in rats. Synapse 37: 167-169.

Anderson SL, Dumont NL, Teicher MH (1997): Developmental differences in dopamine synthesis inhibition by (+/-)-7-OH-DPAT. Naunyn Schmiedebergs Arch Pharmacol 356:173-181.
Aoyama T, Yamamoto K, Kotaki H, Sawada Y, Iga T (1997): Pharmacodynamic modeling for change of locomotor activity by methylphenidate in rats. Pharm Res 14:1601-1606.

- Badanich KA, Maldonado AM, Kirstein CL (2008): Early adolescents show enhanced acute cocaine-induced locomotor activity in comparison to late adolescent and adult rats. Dev Psychobiol 50:127-133. 
Bowman BP, Blatt B, Kuhn CM (1997): Ontogeny of the behavioral response to dopamine agonists after chronic cocaine. Psychopharmacology (Berl) 129:121-127.

-Butcher SP, Liptrot J, Aburthnott GW (1991): Characterisation of methylphenidate and nomifensine induced dopamine release in rat striatum using in vivo brain microdialysis. Neurosci Lett 122:245-248.

-Cao J, Lotfipour S, Loughlin SE, Leslie FM (2007): Adolescent maturation of cocainesensitive neural mechanisms. Neuropsychopharmacology 32:2279-2289.

- Caster JM, Walker QD, Kuhn CM (2005): Enhanced behavioral response to repeateddose cocaine in adolescent rats. Psychopharmacology (Berl) 183:218-225.

Caster JM, Walker QD, Kuhn CM (2007): A single high dose of cocaine induces differential sensitization to specific behaviors across adolescence. Psychopharmacology (Berl) 193: 247-260.

Catlow BJ, Kirstein CL (2005): Heightened cocaine-induced locomotor activity in adolescent compared to adult female rats. J Psychopharmacol 19:443-447.

Catlow BJ, Kirstein CL (2007): Cocaine during adolescence enhances dopamine in response to a natural reinforcer. Neurotoxicol Teratol 29:57-65.

Chen JF, Weiss B (1991): Ontogenetic expression of $\mathrm{D} 2$ dopamine receptor $\mathrm{mRNA}$ in rat corpus striatum. Brain Res Dev Brain Res 63: 95-104.

Chen YI, Choi JK, Andersen SL, Rosen BR, Jenkins BG (2005): Mapping dopamine D2/D3 receptor function using pharmacological magnetic resonance imaging. Psychopharmacology (Berl) 180:705-715.

Chen YI, Galpern WR, Brownell AL, Matthews RT, Bogdanov M, Isacson O, Keltner JR, Beal MF, Rosen BR, Jenkins BG (1997): Detection of dopaminergic neurotransmitter activity using pharmacologic MRI: correlation with PET, microdialysis, and behavioral data. Magn Reson Med 38:389-398.

-Chen YI, Mandeville JB, Nguyen TV, Talele A, Cavagna F, Jenkins BG (2001): Improved mapping of pharmacologically induced neuronal activation using the iron technique with superparamagnetic blood pool agents. J Magn Reson Imaging 14:517-524.

Choi JK, Chen YI, Hamel E, Jenkins BG (2006): Brain hemodynamic changes mediated by dopamine receptors: role of the cerebral microvasculature in dopamine-mediated neurovascular coupling. Neuroimage 30:700712 .

Collins SL, Izenwasser S (2004): Chronic nicotine differentially alters cocaine-induced locomotor activity in adolescent vs. adult male and female rats. Neuropharmacology 46: 349-362.

Cooper JR, Bloom FE, Roth RH (1996): The Biochemical Basis of Neuropharmacology, ed 7. New York, Oxford University Press.
Coulter CL, Happe HK, Murrin LC (1996): Postnatal development of the dopamine transporter: a quantitative autoradiographic study. Brain Res Dev Brain Res 92:172-181.

Court JA, Perry EK, Johnson M, Piggott MA, Kerwin JA, Perry RH, Ince PG (1993): Regional patterns of cholinergic and glutamate activity in the developing and aging human brain. Brain Res Dev Brain Res 74:73-82.

Cox RW, Hyde JS (1997): Software tools for analysis and visualization of fMRI data. NMR Biomed 10:171-178.

-Crawford CA, Rowlett JK, McDougall SA, Bardo MT (1994): Age-dependent differences in the rate of recovery of striatal dopamine D1 and D2 receptors after inactivation with EEDQ. Eur J Pharmacol 252:225-231.

Creese I, Sibley DR, Xu SX (1992): Expression of rat striatal D1 and D2 dopamine receptor mRNAs: ontogenetic and pharmacological studies. Neurochem Int 20(suppl):45S-48S.

du Bois TM, Hsu CW, Li Y, Tan YY, Deng C, Huang XF (2008): Altered dopamine receptor and dopamine transporter binding and tyrosine hydroxylase mRNA expression following perinatal NMDA receptor blockade. Neurochem Res 33:1224-1231.

Feigenbaum JJ, Howard SG (1997): Effects of naloxone on amphetamine induced striatal dopamine release in vivo: a microdialysis study. Life Sci 60:1659-1668.

Ferone D, Saveanu A, Culler MD, Arvigo M, Rebora A, Gatto F, Minuto F, Jaquet P (2007): Novel chimeric somatostatin analogs: facts and perspectives. Eur J Endocrinol 156(suppl 1):S23-S28.

Filloux FM, Adair J, Narang N (1996): The temporal evolution of striatal dopamine receptor binding and mRNA expression following hypoxia-ischemia in the neonatal rat. Brain Res Dev Brain Res 94:81-91.

-Flores G, Wood GK, Liang JJ, Quirion R, Srivastava LK (1996): Enhanced amphetamine sensitivity and increased expression of dopamine D2 receptors in postpubertal rats after neonatal excitotoxic lesions of the medial prefrontal cortex. J Neurosci 16:7366-7375.

Frantz K, Babcock D, Van Hartesveldt C (1996) The locomotor effects of a putative dopamine D3 receptor agonist in developing rats. Eur J Pharmacol 302:1-6.

Frantz KJ, O’Dell LE, Parsons LH (2007): Behavioral and neurochemical responses to cocaine in periadolescent and adult rats. Neuropsychopharmacology 32:625-637.

Frantz KJ, Van Hartesveldt C (1999): The locomotor effects of quinpirole in rats depend on age and gender. Pharmacol Biochem Behav 64:821-826.

Galineau L, Kodas E, Guilloteau D, Vilar MP Chalon S (2004): Ontogeny of the dopamine and serotonin transporters in the rat brain: an autoradiographic study. Neurosci Lett $363: 266-271$.
Gelbard HA, Teicher MH, Faedda G, Baldessarini RJ (1989): Postnatal development of dopamine $\mathrm{D} 1$ and $\mathrm{D} 2$ receptor sites in rat striatum. Brain Res Dev Brain Res 49:123-130.

Gogtay N, Giedd JN, Lusk L, Hayashi KM, Greenstein D, Vaituzis AC, Nugent TF 3rd, Herman DH, Clasen LS, Toga AW, Rapoport JL, Thompson PM (2004): Dynamic mapping of human cortical development during childhood through early adulthood. Proc Natl Acad Sci USA 101:8174-8179.

Guennoun R, Bloch B (1992): Ontogeny of D1 and DARPP-32 gene expression in the rat striatum: an in situ hybridization study. Brain Res Mol Brain Res 12:131-139.

- Huttenlocher PR (1984): Synapse elimination and plasticity in developing human cerebral cortex. Am J Ment Defic 88:488-496.

Ito R, Dalley JW, Robbins TW, Everitt BJ (2002): Dopamine release in the dorsal striatum during cocaine-seeking behavior under the control of a drug-associated cue. J Neurosci 22:6247-6253.

Johansson B, Georgiev V, Fredholm BB (1997): Distribution and postnatal ontogeny of adenosine A2A receptors in rat brain: comparison with dopamine receptors. Neurosci 80 : 1187-1207.

Johnstone AC, Lea RA, Brennan KA, Schenk S, Kennedy MA, Fitzmaurice PS (2007): Benzylpiperazine: a drug of abuse? J Psychopharmacol 21:888-894.

Jung AB, Bennett JP Jr (1996): Development of striatal dopaminergic function. I. Pre- and postnatal development of $m$ RNAs and binding sites for striatal D1 (D1a) and D2 (D2a) receptors. Brain Res Dev Brain Res 94:109120.

Kalsbeek A, Voorn P, Buijs RM, Pool CW, Uylings HB (1988): Development of the dopaminergic innervation in the prefrontal cortex of the rat. J Comp Neurol 269:58-72.

Kraft M, Noailles P, Angulo JA (2001): Substance $\mathrm{P}$ modulates cocaine-evoked dopamine overflow in the striatum of the rat brain. Ann NY Acad Sci 937:121-131.

Kuczenski R, Segal DS, Aizenstein ML (1991): Amphetamine, cocaine, and fencamfamine: relationship between locomotor and stereotypy response profiles and caudate and accumbens dopamine dynamics. J Neurosci 11: 2703-2712.

Lin MY, Walters DE (1994): Dopamine D2 autoreceptors in rats are behaviorally functional at 21 but not 10 days of age. Psychopharmacology (Berl) 114:262-268.

Mandeville JB, Jenkins BG, Chen YI, Choi JK, Kim YR, Belen D, Liu C, Kosofsky BE, Marota JJ (2004): Exogenous contrast agent improves sensitivity of gradient-echo functional magnetic resonance imaging at $9.4 \mathrm{~T}$. Magn Reson Med 52:1272-1281.

Mandeville JB, Jenkins BG, Kosofsky BE, Moskowitz MA, Rosen BR, Marota JJ (2001): Regional sensitivity and coupling of bold and $\mathrm{CBV}$ changes during stimulation of rat brain. Magn Reson Med 45:443-447. 
-Marota JJ, Mandeville JB, Weisskoff RM, Moskowitz MA, Rosen BR, Kosofsky BE (2000): Cocaine activation discriminates dopaminergic projections by temporal response: an fMRI study in rat. Neuroimage 11:13-23.

- McDougall SA, Arnold TF, Nonneman AJ (1990): Ontogeny of locomotor activity and grooming in the young rat: role of dopamine D1 And D2 receptors. Eur J Pharmacol 186: 223-230.

-McDougall SA, Crawford CA, Nonneman AJ (1992): Effects of irreversible dopamine receptor inactivation on locomotor activity and grooming in the 17-and 90-day-old rat. Psychopharmacology (Berl) 106:502-510.

- McNab F, Varrone A, Farde L, Jucaite A, Bystritsky P, Forssberg H, Klingberg T (2009): Changes in cortical dopamine D1 receptor binding associated with cognitive training. Science 323:800-802.

-Montague DM, Lawler CP, Mailman RB, Gilmore JH (1999): Developmental regulation of the dopamine D1 receptor in human caudate and putamen. Neuropsychopharmacology 21:641-649.

-Moody CA, Spear LP (1992a): Ontogenetic differences in the psychopharmacological responses to separate and combined stimulation of D1 and D2 dopamine receptors during the neonatal to weanling age period. Psychopharmacology (Berl) 106:161-168.

Moody CA, Spear LP (1992b): Effects of acute dopamine depletion on responsiveness to D1 and D2 receptor agonists in infant and weanling rat pups. Psychopharmacology (Berl) 107:39-49.

Murrin LC, Zeng W (1986): Postnatal ontogeny of dopamine D2 receptors in rat striatum. Biochem Pharmacol 35:1159-1162.

-Murrin LC, Zeng WY (1990): Ontogeny of dopamine D1 receptors in rat forebrain: a quantitative autoradiographic study. Brain Res Dev Brain Res 57:7-13.

O'Donnell S, Noseworthy MD, Levine B, Dennis M (2005): Cortical thickness of the frontopolar area in typically developing children and adolescents. Neuroimage 24:948-954.

- Parylak SL, Caster JM, Walker QD, Kuhn CM (2008): Gonadal steroids mediate the opposite changes in cocaine-induced locomotion across adolescence in male and female rats. Pharmacol Biochem Behav 89:314-323.

Paxinos G, Watson C (1997): The Rat Brain in Stereotaxic Coordinates. San Diego, Academic Press.

- Porras G, De Deurwaerdere P, Moison D, Spampinato $U$ (2003): Conditional involvement of striatal serotonin 3 receptors in the control of in vivo dopamine outflow in the rat striatum. Eur J Neurosci 17:771-781.

- Rao PA, Molinoff PB, Joyce JN (1991): Ontogeny of dopamine $\mathrm{D} 1$ and $\mathrm{D} 2$ receptor subtypes in rat basal ganglia: a quantitative autoradiographic study. Brain Res Dev Brain Res 60: 161-177.
Ren J, Xu H, Choi JK, Jenkins BG, Chen YI (2009): Dopaminergic response to graded dopamine concentration elicited by four amphetamine doses. Synapse 63:764-772.

Richfield EK, Penney JB, Young AB (1989): Anatomical and affinity state comparisons between dopamine D1 and D2 receptors in the rat central nervous system. Neurosci 30:767777.

Sales N, Martres MP, Bouthenet ML, Schwartz JC (1989): Ontogeny of dopaminergic D-2 receptors in the rat nervous system: characterization and detailed autoradiographic mapping with [125i]iodosulpride. Neuroscience 28:673-700.

-Schambra UB, Duncan GE, Breese GR, Fornaretto MG, Caron MG, Fremeau RT Jr (1994): Ontogeny of D1a and D2 dopamine receptor subtypes in rat brain using in situ hybridization and receptor binding. Neuroscience 62 : 65-85.

Schoemaker H, Claustre Y, Fage D, Rouquier L, Chergui K, Curet O, Oblin A, Gonon F, Carter C, Benavides J, Scatton B (1997): Neurochemical characteristics of amisulpride, an atypical dopamine D2/D3 receptor antagonist with both presynaptic and limbic selectivity. J Pharmacol Exp Ther 280:83-97.

-Schwarz AJ, Danckaert A, Reese T, Gozzi A, Paxinos G, Watson C, Merlo-Pich EV, Bifone A (2006): A stereotaxic MRI template set for the rat brain with tissue class distribution maps and coregistered anatomical atlas: application to pharmacological MRI. Neuroimage 32:538-550.

- Schwarz AJ, Zocchi A, Reese T, Gozzi A, Garzotti M, Varnier G, Curcuruto O, Sartori I, Girlanda E, Biscaro B, Crestan V, Bertani S, Heidbreder C, Bifone A (2004): Concurrent pharmacological MRI and in situ microdialysis of cocaine reveal a complex relationship between the central hemodynamic response and local dopamine concentration. Neuroimage 23:296-304.

Shaw P, Kabani NJ, Lerch JP, Eckstrand K, Lenroot R, Gogtay N, Greenstein D, Clasen L, Evans A, Rapoport JL, Giedd JN, Wise SP (2008): Neurodevelopmental trajectories of the human cerebral cortex. J Neurosci 28: 3586-3594.

-Shen T, Weissleder R, Papisov M, Bogdanov A Jr, Brady TJ (1993): Monocrystalline iron oxide nanocompounds (MION): physicochemical properties. Magn Reson Med 29:599-604.

-Smith KS, Morrell JI (2008): Behavioral responses during the initial exposures to a low dose of cocaine in late preweanling and adult rats. Neurotoxicol Teratol 30:202-212.

- Spear LP, Brake SC (1983): Periadolescence: agedependent behavior and psychopharmacological responsivity in rats. Dev Psychobiol 16:83-109.
-Srivastava LK, Morency MA, Mishra RK (1992): Ontogeny of dopamine D2 receptor mRNA in rat brain. Eur J Pharmacol 225:143-150.

-Stanwood GD, McElligot S, Lu L, McGonigle P (1997): Ontogeny of dopamine D3 receptors in the nucleus accumbens of the rat. Neurosci Lett 223:13-16.

- Strange PG (2005): Oligomers of D2 dopamine receptors: evidence from ligand binding. J Mol Neurosci 26:155-160.

- Sulzer D, Sonders MS, Poulsen NW, Galli A (2005): Mechanisms of neurotransmitter release by amphetamines: a review. Prog Neurobiol 75:406-433.

- Tanda G, Ebbs A, Newman AH, Katz JL (2005): Effects of 4'-chloro-3 alpha(diphenylmethoxy)-tropane on mesostriatal, mesocortical, and mesolimbic dopamine transmission: comparison with effects of cocaine. J Pharmacol Exp Ther 313:613-620.

- Teicher MH, Barber NI, Gelbard HA, Gallitano AL, Campbell A, Marsh E, Baldessarini RJ (1993): Developmental differences in acute nigrostriatal and mesocorticolimbic system response to haloperidol. Neuropsychopharmacology 9:147-156.

- Tropea TF, Guerriero RM, Willuhn I, Unterwald EM, Ehrlich ME, Steiner H, Kosofsky BE (2008): Augmented D1 dopamine receptor signaling and immediate-early gene induction in adult striatum after prenatal cocaine. Biol Psychiatry 63:1066-1074

-Van Hartesveldt C, Meyer ME, Potter TJ (1994): Ontogeny of biphasic locomotor effects of quinpirole. Pharmacol Biochem Behav 48: 781-786.

Villringer A, Rosen BR, Belliveau JW, Ackerman JL, Lauffer RB, Buxton RB, Chao YS, Wedeen VJ, Brady TJ (1988): Dynamic imaging with lanthanide chelates in normal brain: contrast due to magnetic susceptibility effects. Magn Reson Med 6:164-174.

-Vivo M, Lin H, Strange PG (2006): Investigation of cooperativity in the binding of ligands to the $\mathrm{D}(2)$ dopamine receptor. Mol Pharmacol 69:226-235

Weiss B, Chen JF, Zhang S, Zhou LW (1992): Developmental and age-related changes in the D2 dopamine receptor mRNA subtypes in rat brain. Neurochem Int 20(suppl):49S$58 \mathrm{~S}$.

-Wurch T, Matsumoto A, Pauwels PJ (2001): Agonist-independent and -dependent oligomerization of dopamine $\mathrm{D}(2)$ receptors by fusion to fluorescent proteins. FEBS Lett 507: 109-113.

Zecevic N, Bourgeois JP, Rakic P (1989): Changes in synaptic density in motor cortex of rhesus monkey during fetal and postnatal life. Brain Res Dev Brain Res 50:11-32.

Zeng WY, Hyttel J, Murrin LC (1988): Ontogeny of dopamine D1 receptors in rat striatum. J Neurochem 50:862-867. 